\title{
Importance of Tourmaline Gneiss and Vein near Main Central Thrust in Sikkim Darjeeling Himalaya
}

\author{
Tamoghna Saha \\ Department of Geology, Government General Degree College at Pedong, Kalimpong, West Bengal \\ Email: clarkentju@gmail.com
}

How to cite this paper: Saha, T. (2020) Importance of Tourmaline Gneiss and Vein near Main Central Thrust in Sikkim Darjeeling Himalaya. Open Journal of Geology, 10, 552-564.

https://doi.org/10.4236/ojg.2020.105024

Received: April 29, 2020

Accepted: May 25, 2020

Published: May 28, 2020

Copyright ( 2020 by author(s) and Scientific Research Publishing Inc. This work is licensed under the Creative Commons Attribution International License (CC BY 4.0).

http://creativecommons.org/licenses/by/4.0/

\section{(c) (i) Open Access}

\begin{abstract}
Lingtse gneiss (LGn) and Higher Himalayan crystallines (HHC) comprise parts of main central thrust (MCT) in the Darjeeling Sikkim Himalaya. Tourmaline bearing gneiss and quartz tourmaline veins are reported in immediate contact with the LGn and some lesser Himalayan rocks in this study. Their importance is inferred via their comparative occurrence, micro-texture and chemistry. Flow of ductile crust was proposed to expose deep crustal rocks in the Himalayas in form of these gneissic rocks. Generation of paragneissic HHC from the protolith like the lesser Himalayan rocks like biotite-muscovite schist was proposed and documented in previous studies. The main central thrust where the principal motion is reported to date at circa 20 $\mathrm{Ma}$ appears in the contact regions of the HHC and lesser Himalayan rocks. Whether the tourmaline bearing gneiss or veins is a product during the episode of generation of the Higher Himalayan crystallines, which is taken as a component of the higher Himalayan crystallines episode remains a question as both concordant and discordant tourmaline bearing gneiss and/or quartzo-feldspahic veins appear respectively. The $\mathrm{mm}-\mathrm{cm}$ scale tourmaline in the occasionally discordant quartz tourmaline veins shows strong zonation and less effects of shearing. Those are strongly zoned indicating magmatic hydrothermal character. The matrix tourmaline shows a separate composition. However, evidences of a less prominent shearing in them might signify rejuvenation. Lower temperature activity and fluid movement in this thrust zone are signified from the microstructure signifying that the high grade main central thrust was probably rejuvenated during or after the veining.
\end{abstract}

\section{Keywords}

Lingtse Gneiss, Main Central Thrust, Tourmaline, Himalaya, Quartzofeldspathic Vein 


\section{Introduction}

There are two broad subdivisions or rock types found in the study area (Figure 1). One rock type is categorized as the lesser Himalayan sequence consisting of schistose rocks with biotite, muscovite, chlorite as the principal constituent mineral phases alternating with the quartz and feldspar. On the other hand, the Higher Himalayan crystalline (HHC) comprises North and North East sectors of the study area. The Lingtse gneiss which is the basement rock [1] sometimes occurs as bands or dykes and thick metre-km scale bands throughout the MCT and within the lesser Himalayas in the area. The regional isograd in this region creating the HHC was modelled by [2] and was later investigated to understand the evolutionary sequence through U-Pb dating [3]. They have inferred an event of peak metamorphism and melting generating garnet in these rocks at the cost of pre-existing hydrous minerals like muscovite. HHC is considered to be paragneissic and their whole rock isochron age is supposed to be around $\mathrm{Pa}$ laeo-Mesoproterozoic [4]. Tourmaline bearing gneiss is reported from the HHC as intrusive pegmatites from the Arunachal Himalaya [5] where the tourmaline is thought as a primary mineral. Earlier palaeoproterozoic metamorphism in the LHS (lesser Himalayan rocks or sequence) generating garnet was also inferred by [6]. On the contrary the metamorphism generating the HHC and melt was discussed to take place at $31 \mathrm{Ma}-15 \mathrm{Ma}$ (Rubatto et al., 2013). However, peak of metamorphicm was documented at $13-11 \mathrm{Ma}$ by [7] in this zone. The inverted metamorphic sequence was referred as a resultant from thrusting. Similar types of rocks are separated from the lesser Himalayan sequence (LHS) by a thrust through a sheared contact region all over the Himalayas. However, there are questions to delineate this thrust contact in between the LHS and HHC group of rocks based upon $\mathrm{Rb} / \mathrm{Sr}$ and $\mathrm{Sm} / \mathrm{Nd}$ isotopic systematic [8] study. Like the MCT there are many thrusted and faulted contact regions in the Himalayas transecting from North to South. The Lingtse gneiss is a porphyritic rock found in close vicinity to the MCT, an orthogneissic porphyritic unit. The footwall side that is the Indian side [9] and the hanging wall sides show contrasting isotopic and geochemical signs along with different generations of granitic intrusions. However, the motion of the final thrusting in the MCT is Cenozoic during the India and Asia convergence. The age of emplacement of LGn in these orthogneissic units in the Himalayas also indicates a broad temporal spectrum during a time period of $1800-1900 \mathrm{Ma}$ ([4] [10]). Both the gneissic rocks and the HHC were emplaced by migration by lowering of viscosity during rise in temperature and fall in viscosity during channel flow ([11] [12]). A diachroneity of the evolution of the HHC in this region was raised by few workers [3]. Some workers [13] had inferred extra influence of fault slice bounded tectonic process to act within the already emplaced LGn citing few earlier works [14] on depth dependent rheology. However, Chakraborty et al. (2016) [7] have relied upon little evidences of shearing within the metapelitic units of the LHS and they inferred that these units had acted as coherent viscous blocks. There they had corroborated that the rocks were uplifted not only by channel flow but by regions 


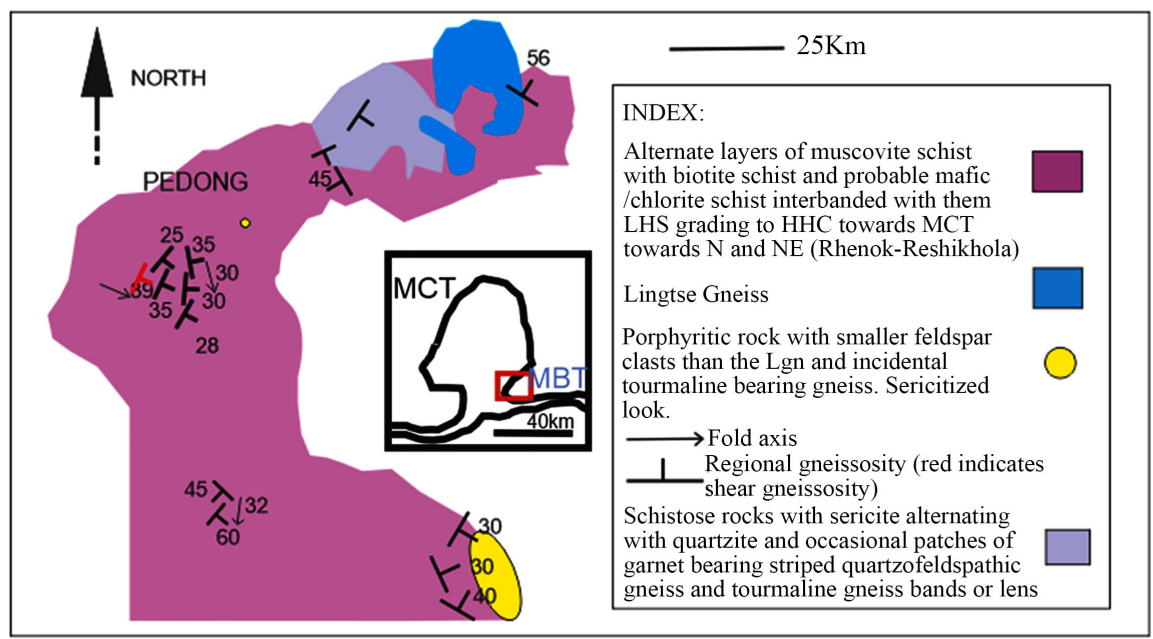

Figure 1. The subdivisions and the rocks exposed in the study area as described in the inset. The regional position of the study area is given to the venter of the inset. The shear band is shown in red. The sericite bearing rocks, LGn and tourmaline bearing horizon also bear the shear bands parallel to the regional gneissic fabric shown in the map. For the inset, the rock types to the North and South are not shown. The upper bounding surface is the MCT. The lower bounding surface is the Main Boundary Thrust (MBT). The squared area shows the area of field. The inset is taken from Mottram et al. (2013). The Northern portions to the MCT are principally composed of HHC and the portion between the MBT and MCT is composed of LHS.

bounded by ductile fault zones. However, the MCT shows evidences of tectonic imbrication [9] and inferred juxtaposition of rocks of different isotopic characters in this region.

This study takes into account few tourmaline bearing veins and tourmaline bearing gneiss in immediate contact with the LGn from the Sikkim Darjeeling Himalaya. Tourmaline is a ring silicate that can sustain high to ultra-high pressure and high temperature situations (Hinsberg et al., 2011 and references cited there in [15]). They have prismatic habit and can crystallize from magmatic, metamorphic to hydrothermal conditions. The low diffusivity of major and trace element makes it a good indicator for pre-existing geological conditions. That's why the tourmaline gneiss and the tourmaline bearing quartzofeldspathic veins can be potential for constraining the metamorphic history of this area. They also gave an idea regarding the fluid activity along the thrust planes during periods of rejuvenation. The occurrence of MCT can also be delineated from a closer observation of the tourmaline bearing veins and tourmaline gneiss from the study area. This study focuses in some observations made from a contact zone between the LHS and LGn where the LGn was spotted as unit intercalated with the LHS and the tourmaline bearing gneiss. The LHS, however grades to HHC towards East transecting the MCT.

\section{Outcrop Scale Studies}

Lingtse Gneiss (LGn) is a heterogeneous rock with alternate bands made of biotite, ilmenite composing melanocratic bands and leucocratic bands made up of 
quartz and feldspar (Figure 2(a)). There are occasional coarse garnet which appears stretched along the shear gneissic banding (Figure 2(b)) in close vicinity to the sheared variants of the LGn. The rock sometimes gives rise to augen gneissic fabric because of stretched minerals like quartz and feldspar. These feldspar clasts and garnet appear embedded in quartzofeldspathic melt signifying a melting high grade metamorphism and melting episode. The quartzofeldspathic network creates veins through the pre-existing feldspar clasts related to deformation and partial melting episodes after their emplacement (Figure 2(c)). The contact between LGn and tourmaline bearing gneiss appears sharp (Figure $2(d))$ in outcrop. Near the outcrop scale contact regions, these tourmaline bearing gneiss intercalated with the LGn bear the felsic vein materials (Figure 2(e), Figure 2(f)) occasionally. These are mostly rich in quartz. The contact is diffusive at their $\mathrm{mm}$ to $\mathrm{cm}$ scale though. Hence, there are two types of contact domains between the tourmaline bearing rocks and LGn. One variant shows concordance and is gneissic while the other is rich in quartzofeldspathic melt and discordant. There is another variant of gneissic rock which can be observed intercalated with the lesser Himalayan crystallines in the study area. They are striped to massive in look and are composed of alternate leucocratic and melanocratic minerals with occasional garnet. This promotes further questions about the actual boundary and contact relationship with the schist of the lesser Himalaya and LGn and this striped gneiss. The lesser Himalayan sequence composed of package of biotite-chlorite-muscovite schist grade to HHC near the folded and thrusted MCT of the study area. The lesser Himalayan rocks preserve evidences of no planar non cylindrical deformation in form of folds (Figure $2(\mathrm{~g})$ ) with changing trend of pre-existing axial planar gneissosity and changing trend of the fold axes (Figure 1) observed in the schistose lower grade units (Figure 2(h)). Striped gneiss in the LHS was proposed to be another counterpart of LGn by Sinha Roy (1982) [16]. Few of the lesser Himalayan muscovite schist \pm quartzite of the study area bear garnet porphyroblast bearing quartzofeldpsathic bands running concomitant to the gneissic fabric and are often associated with melanocratic bands in the LHS and potentially are palaeoproterozoic in character [6]. The lesser Himalayan crystallines bear folded schistosity where the changing trend of the fold axis or pucker axis indicates non-cylindricity also inferable from the regional litho-structural map (Figure 1). The contact between the HHC and the LHS is a zone of sericitizaton and shear deformation where the LGn is preponderant. Towards the North and North East presence of HHC within host of LHS and creating diffusive contact indicates a pervasive melting during a peak event of metamorphism. However, this region lies East and far from the outcrop of tourmaline baring gneiss and quart tourmaline vein reported in this study.

\section{Petrographic Observations and Discussion}

The quartz grains are $5-8 \mathrm{~mm}$ in length and $3-4 \mathrm{~mm}$ wide under microscope in the LGn. They often show partial and undulose extinction. The larger grains 

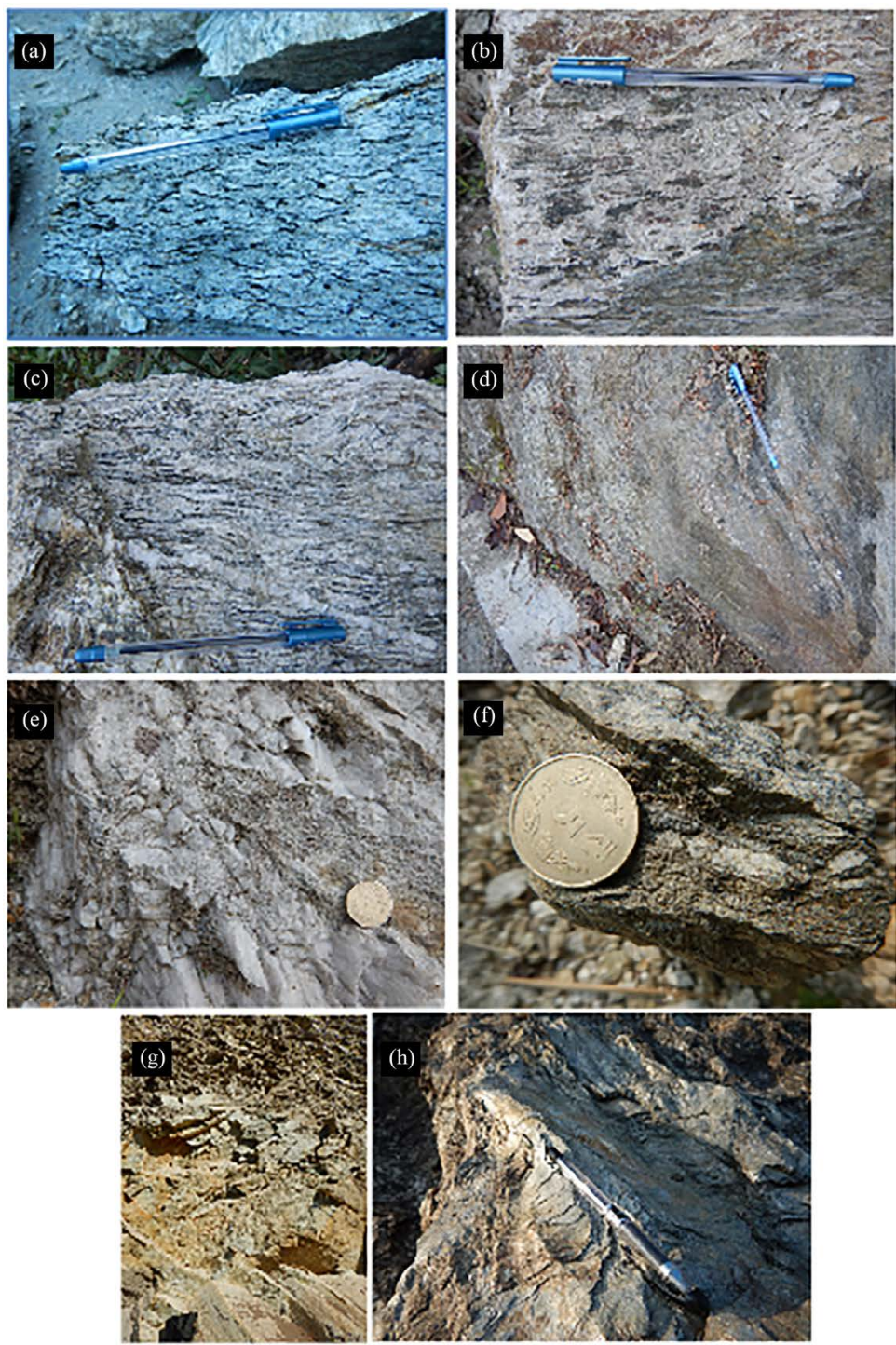

Figure 2. (a) Typical look of the Lingtse porphyritic gneiss forming augens of felsic phases with visible $\mathrm{C} / \mathrm{S}$ fabric in the rock; (b) Large garnet bearing clast wrapped within quartzofeldspathic melt in the LGn; (c) Quartzofeldspathic vein inside LGn; (d) Diffusive to sharp contact between the LGn and tourmaline gneiss; (e) Veining material within the tourmaline bearing gneiss containing garnet clast creating sharp to diffusive contact with the host; (f) vein with sharp contact with the tourmaline gneiss; (g) The refolded axial plane in a unit of LHS creating recumbent feature; $(\mathrm{h})$ fold axis or pucker lineation in a schistose unit within LHS.

are anhedral and develop subgrains at their boundary (Figure 3(a)) and protrude neighbouring quartz and feldspar grains in bulging relationship. The creation of subgrains around large anhedral grains of quartz implies low to moderate degrees of temperature during the recrystallization episode [17]. The phyllosilicates like biotite and muscovite dominate the shear bands and quartz form lenticular features and that also testifies a low temperature, hydrous shear zone development. Workers (1982) established that mylonitized LGn were mostly sericitized in character. However, the presence of C-S fabric in non sericitized rocks 

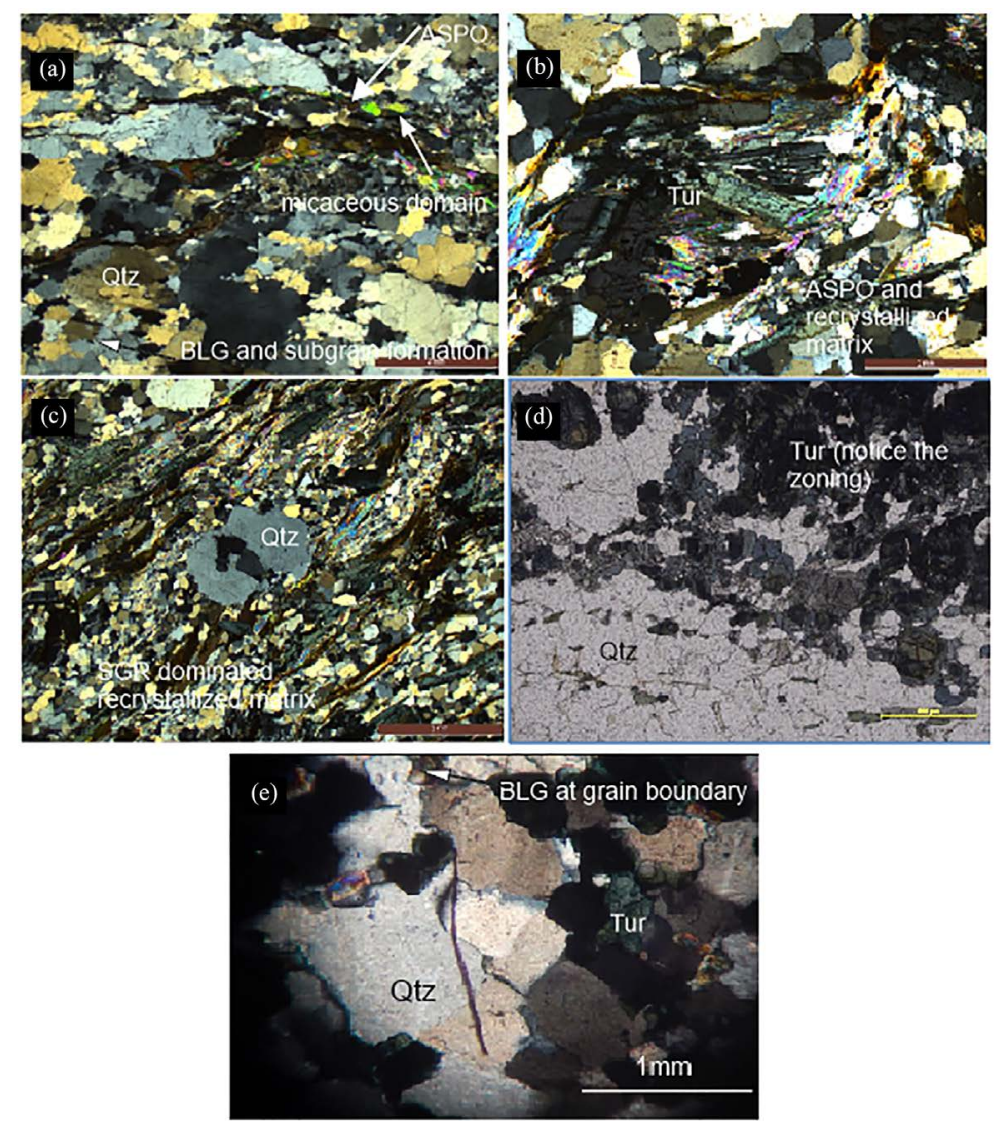

Figure 3. (a) Stretched grains of quartz in LGn which had suffered shearing of medium intensity and there are serration at their boundary. Subgrains are clear. Notice biotite and other phyllosilicates between the quartzofeldspathic layers. (Mineral names are abbreviated following [29]); (b) recrystallized tourmaline feldspar aggregate in the tourmaline bearing gneiss. The upper left quadrant shows bulging relation and formation of medium subgrains. The right hand side shows formation of newer smaller grains; (c) Porphyroclastic quartz in a sub grain rotation dominated recrystallized matrix. The clear alteration of melanocratic and leucocratic layers can be observed in the tourmaline gneiss; (d) Tourmaline-quartz vein with zoning (Fe/Mg in a few $\mathrm{X}$ ray images) in tourmaline is clear. Note the matrix tourmaline shows a crude orientation; (e) BLG dominated deformation in the vein indicating lowest grade of deformation with a matrix tourmaline.

imply that shearing was effective upon the non sericitized rocks also. Aggregates of smaller quartz grains often create straight $60^{\circ}-120^{\circ}$ triple junction being pinned by smaller biotite flakes in the matrix. These are evidently resultant from static recrystallization [18]. Some workers [19] documented certain microstructural features from the Daling thrust (DT) or MCT 1 which is the lower bounding surface of MCT. They inferred subgrain rotation dominated recrystallization away from the DT implying a higher temperature recrystallization away from the thrust contact. The rocks from our study on the other hand show occasional evidences for the subgrain rotation (SGR) under petrographic microscope. These domains show gradational variation, from equal polygonal aggregate composed of quartz to elongated and rotated straightened boundary region of smaller quartz grains in the tourmaline bearing gneiss and the LGn also. Muscovite and 
biotite comprises aggregate shape preferred fabric along gneissosity. Like quartz, alkali feldspar shows protruding boundary with quartz grains with bulging recrystallization (BLG). Alkali feldspar occasionally shows perthitic texture. Chlorite is rarely present along with biotite and muscovite aggregates along the gneissosity. These features imply the last deformation event took place at low to medium temperature and in a possible hydrous environment. Splay faults to play a major role in forming thrust slices exposing LGn (fault slice bounded tectonics mechanism) and was previously proposed [13]. They also notified preponderance of a depth dependent rheology associated with LGn citing Faccenda et al. (2008) [20] in their review. This mechanism was proposed by Mukherjee et al. (2013) in the HHC with taper cone mechanism. They inferred a simple shear assisted with vertical pressure gradient causing channel flow like behaviour in these rocks.

For the heterogeneous tourmaline bearing gneiss, the melanocratic bands are composed of blades of tourmaline, chlorite, biotite, apatite, quartz (Figure 3(b), Figure $3(\mathrm{c})$ ). The leucocratic layers are composed with polygonal aggregates of quartz and alkali feldspar. Occasionally they look porphyritic in the field and the gneissosity is defined by clasts of feldspar and alternate tourmaline, biotite and chlorite bearing flakes. Apatite sometimes form clasts wrapped by hydrous mineral and quartz in the matrix. Occasionally, quartz creates bulging recrystallization (BLG) dominated contact with neighbouring phases between the phyllosilicate. Larger quartz grains develop subgrains at their boundary with development of smaller recrystallized grains. The smaller grains create polygonal assemblage. This implies recrystallization during cooling from high temperature. The polygonal aggregate of quartz are pinned by biotite and chlorite at their boundary and they develop aggregate shape preferred orientation. The difference between the LGn and tourmaline bearing gneiss lies in the mineralogy. Sometimes the smaller recrystallized grain of quartz in the band are aligned and appears typically sub grain rotation dominated fabric. The observations question whether there is any need to correlate tourmaline bearing granite gneiss with MCT development as more deformed and serrated ASPO is found in them. The felsic veins discussed in section 1 within the tourmaline bearing gneiss also contains polygonal and serrated aggregates of quartz and alkali feldspar and imply a similar microstructural character to the host KGn or the HHC.

The tourmaline clasts in the veins which crosscut the earlier pervasive gneissic fabric in the LGn or runs through the fabric of the tourmaline gneiss show zoned character under petrographic microscope (Figure $3(\mathrm{~d})$ ). The fractured grains found in the discordant veins indicate an event of alteration and their genesis later than the euhedral to subhedral tourmaline in the gneiss. There is a lack in the aggregate shape preferred orientation (Figure 3(e)) in the quartz bearing bulk encroaching tourmaline clasts. However, the wrapping fabric around the quartz-tourmaline island shows presence of shear bands. There the tourmaline and quartz appear stretched. This symbolizes a pulsating nature of deformation during or after a pre-existing episode of shearing in higher grade. 


\section{Geochemical Complexities, Metamorphism and Tectonics}

The broad age range of the porphyritic granite like the LGn as of also seen in form of striped gneiss and LGn as discussed arises a question how a single magmatic event can prevail long for the whole period of nearly more than 100 million years (Bhattacharyya et al., 2015 and references). A second episode of metamorphism might also have reset the geochemical signatures in the LGn. The Lingtse gneiss also conforms with a global orogenic episode called Hudsonian orogeny around c a $1.7-1.8 \mathrm{Ma}$ [4] during the formation of Columbia. $\mathrm{Rb} \mathrm{Sr}$ whole rock isochron [21] of Lingtse gneiss was documented to be $1.79 \mathrm{Ga}$ and zircon weighted mean age of $1.835 \mathrm{Ga}$ with $(\mathrm{Th} / \mathrm{U})$ in zircons was documented for the Lingtse gneiss. Streaky/striped gneissic units from the LGn on the other hand were documented to preserve whole rock isochron age near 1.08 $\mathrm{Ga}$ [22] and might be a result of later metamorphism episodes. Pulses of magmatic episodes are also well documented from the Himalayas till date. However, the question remain how did the Lingtse gneiss sustain the signs of S and I type granites in spite of multiple tectonometamorphic cycles of the Himalayas. Workers had inferred effects of metamorphism after the emplacement in these granitoids. The alkaline and alkali calcic character [22] in the LGn are fascinating and whether they are product geochemical signatures of multiple orogenic episodes and melt transfer in the crust is a big question. The fractionated nature of these granitoids determined from the $\mathrm{La} / \mathrm{Lu}$ ratio [21] is also important as fractionation of a precursor mafic magma is capable to generate A type anorogenic granites ([23] [24]) which is rare in occurence. This will give us a much clear idea about the tectonic setting of their genesis. Pulses of an accretion collision dynamics accreting new crustal magma can vary in age. These events might be short lived or long lived. Hence, the geochemistry and preserved textural features might suggest the true evolutionary character of the LGn. In this context, the tourmaline blades in the concordant tourmaline gneiss within the LGn can be informative as they can bear signs of earliest metamorphic or igneous milieu. The appearance of the euhedral to subhedral blades of tourmaline in interlocking texture can give an idea of its source. That may also help scrutinize the tectonic setting of their formation. Few analysed grains show schorl-dravite series of composition typical of metasediments [25] for both the core and zoned rim in EPMA analysis from the discordant bodies of tourmaline bearing quartzofeldspathic lens or veins concomitant to the tourmaline bearing gneiss or LGn (Table 1; The zoning is also visible in the $\mathrm{X}$ ray intensity maps. Analyses were done from IIT, Kharagpur EPMA analytical facility. The measured elements were set at $10 \mathrm{~s}$ for the peak and $5 \mathrm{~s}$ for background. The natural standards (and emission lines) used were jadeite ( $\mathrm{Na}-\mathrm{Ka}, \mathrm{Si}-\mathrm{Ka}$ ), diopside (Ca-Ka, $\mathrm{Mg}-\mathrm{Ka}$ ), orthoclase (K-Ka, Al-Ka), fluorapatite (F-Ka, $\mathrm{P}-\mathrm{Ka}$ ), $\mathrm{NaCl}(\mathrm{Cl}-\mathrm{Ka}), \mathrm{Fe}_{2} \mathrm{O}_{3}(\mathrm{Fe}-\mathrm{Ka})$, rhodonite ( $\mathrm{Mn}-\mathrm{Ka}), \mathrm{TiO}_{2}$ ( $\left.\mathrm{Ti}-\mathrm{Ka}\right)$. A thallium acid phthalate (TAP) crystal was used to analyse $\mathrm{F}, \mathrm{Na}, \mathrm{Al}$, Si and $\mathrm{Mg}$; a pentaerythrol (PET) crystal was used for $\mathrm{Ca}$, $\mathrm{Ti}, \mathrm{K}$ and $\mathrm{Cl}$; a large pentaerythryitol (LPET) crystal for $\mathrm{P}$, and a lithium fluoride 
Table 1. Empirical formula recalculation based upon 31'O' (Henry et al., 2011) of the tourmaline in vein from EPMA.

\begin{tabular}{|c|c|c|c|}
\hline & Clast & Clast & Matrix \\
\hline $\mathrm{SiO}_{2}$ & 33.96 & 34.46 & 23.50 \\
\hline $\mathrm{TiO}_{2}$ & 0.13 & 0.24 & 0.03 \\
\hline $\mathrm{Al}_{2} \mathrm{O}_{3}$ & 33.93 & 33.19 & 22.25 \\
\hline $\mathrm{Cr}_{2} \mathrm{O}_{3}$ & 0.00 & 0.09 & 0.00 \\
\hline $\mathrm{FeO}$ & 15.51 & 14.94 & 31.83 \\
\hline $\mathrm{MgO}$ & 0.33 & 0.91 & 9.88 \\
\hline $\mathrm{CaO}$ & 0.25 & 0.29 & 0.02 \\
\hline $\mathrm{MnO}$ & 0.16 & 0.02 & 0.20 \\
\hline $\mathrm{ZnO}$ & 0.00 & 0.00 & 0.04 \\
\hline $\mathrm{BaO}$ & 0.00 & 0.00 & 0.00 \\
\hline $\mathrm{Na}_{2} \mathrm{O}$ & 1.85 & 1.71 & 0.02 \\
\hline $\mathrm{K} 2 \mathrm{O}$ & 0.02 & 0.04 & 0.02 \\
\hline $\mathrm{F}$ & 0.00 & 0.01 & 0.00 \\
\hline $\mathrm{Cl}$ & 0.01 & 0.00 & 0.01 \\
\hline \multicolumn{4}{|c|}{ Based upon 310} \\
\hline $\mathrm{Si}$ & 5.776 & 5.854 & 4.499 \\
\hline $\mathrm{Ti}$ & 0.016 & 0.031 & 0.004 \\
\hline $\mathrm{Cr}$ & 0.000 & 0.012 & 0.000 \\
\hline $\mathrm{Al}$ & 6.802 & 6.645 & 5.020 \\
\hline $\mathrm{Fe}^{3+}$ & 0.000 & 0.000 & 0.000 \\
\hline $\mathrm{Fe}^{2+}$ & 2.207 & 2.122 & 5.096 \\
\hline $\mathrm{Mg}$ & 0.082 & 0.229 & 2.819 \\
\hline $\mathrm{Mn}$ & 0.023 & 0.003 & 0.032 \\
\hline $\mathrm{Zn}$ & 0.000 & 0.000 & 0.006 \\
\hline $\mathrm{Ca}$ & 0.046 & 0.054 & 0.004 \\
\hline $\mathrm{Na}$ & 0.609 & 0.562 & 0.009 \\
\hline $\mathrm{K}$ & 0.005 & 0.008 & 0.005 \\
\hline $\mathrm{Ba}$ & 0.000 & 0.000 & 0.000 \\
\hline $\mathrm{F}$ & 0.002 & 0.007 & 0.000 \\
\hline $\mathrm{Cl}$ & 0.003 & 0.000 & 0.003 \\
\hline
\end{tabular}

(LiF) crystal for Mn and Fe). This connotes to the host as LGn is also quoted as I and S Type of affinity and the HHC is paragneissic. However, there is a significant contrast in the $\mathrm{Fe} / \mathrm{Mg}$ ratio in the core with more iron and the replacive tourmaline along the fracture planes inside the quartzo-feldspathic discordant lens found in the rock. One analysis of euhedral-subhedral tourmaline in the concordant tourmaline gneiss shows foitite like composition which is very dif- 
ferent from schorl-dravite series of tourmaline in the veins and may imply presence of three generations of tourmaline in the study area. The matrix tourmaline in the vein also gives foitite like composition. However, the occurrence of these veins discordant to the LGn and LHS needs melting and concomitant events of shearing without melt loss or partial melt loss. After the genesis of the main central thrust, the source of the melt as can be observed is meta-sedimentary in character and the LHS could be the source. The other possibility of the exhumation of high pressure or ultra-high pressure rocks which is still not reported in the study area. However, the veins and the character of the tourmaline will indicate a multistage exhumation, deformation and tectonic disturbances in this area. The matrix tourmaline in the veins which had shown elongation along the shear gneissic fabric implying presence of boron rich fluid and possible late stages of formation when the residual silica precipitated as quartz. The appearance of quartz with minimal evidence of deformation in these units indicate lenses of less deformed zone within the regional thrusted and sheared contact.

\section{Discussion and Future Prospects}

The structural observations of non-cylindrical folded gneissosity/schistosity indicate a thrust and fold in this region. However, the perception whether LGn defines the MCT also needs to be verified. Generation of migmatitic rocks like HHC will imply breakage of the liquid percolation threshold (LPT) and transfer of melt to the surrounding LGn. That will be more pronounced in case the melt breaks the metamorphic escape threshold (MET) and changes the chemistry of the LGn [26]. This should change the chemistry of the HHC and could have been generated geochemical signatures from LGn not reported. Searle and Szulc (2005) [12] had recently documented the sillimanite grade gneiss from Kangchenjunga section to be intercalated with LGn and they preferred these to be a resultant of melt/vein injection. Whether the concordant bodies or tourmaline gneiss are result of that event is a question. However, discordant bodies of tourmaline bearing veins which show evidences of alteration must be a later event which again shows minor evidences of shearing. But their extent can shade some light on how crustal melt flow could really work. Following events of profuse biotite and muscovite generation during shearing also imply fluid movement during this event. The channel flow mechanism is assisted with the shear deformation which needs melt induced flow mechanism [13] that might had been also affected by this. On the other hand, few workers [27] had deciphered the generation and evolution of this thrust plane in a fluid assisted environment syn-reaction. It is conspicuous how migration of fluid can rectify the rheology of a rock to this extent. Although present works indicate a less effective heating near the shear zones and higher temperature signatures away from the fault zones ([19] [28]) like the MCT1/2, there is a possibility that there was a stark contrast in their rheology and viscosity of these units. Is this the result of retention of the high grade rocks near the MCT which is the cause of its evolution? 
Presence of tourmaline bearing veins (indicating multiple generation) along with the gneissic rock within the LGn through tourmaline gneiss as well as LGn shows us a chance to ensure about the rheology of the rocks by thermobarometric analysis of tourmaline in the veins. As HHC preserves kyanite in a prograde path over sillimanite needles from a few localities from the study area, it is quite [2] evident that it underwent fair amount of high temperature metamorphism before the pressure peak attained for a clockwise Himalayan orogeny generating kyanite over them. Some workers [12] emphasized upon melting of rocks in ductile situations generating sillimanite grade melting in sections from the Darjeeling-Kangchenjunga profile and sudden extrusion of this semi molten rock to surface during Miocene beneath Southern Tibetan detachment. As the tourmaline blades in the tourmaline gneiss are concordant to the LGn and euhedral to subhedral and are different in habit than the tourmaline in the melt network as well as differs in composition, this may also imply multiple generations or evolution of melt from beginning to end. The source of the vein could be remelting of HHC or the host of LHS themselves. However, the event should have an effect upon the processes in the MCT in this region. If this behaviour mineralogy and structure of the vein indicates an early hotter and later high pressure to colder regime of metamorphism holds answers. The investigation upon the tourmaline gneiss may also help to indicate the fluid assisted fault bound tectonics whether was preponderant near MCT 1/2. On the other hand the presence of the tourmaline gneiss in the LGn a result from tectonic imbrication during thrusting and a later veining periodically affected by shear events in the MCT is also an important question to resolve.

\section{Conflicts of Interest}

The author declares no conflicts of interest regarding the publication of this paper.

\section{References}

[1] Sinha Roy, S. and Sengupta, S. (1986) Precambrian Deformed Granites of Possible Basement in the Himalayas. Precambrian Research, 31, 209-235. https://doi.org/10.1016/0301-9268(86)90074-4

[2] Neogi, S., Dasgupta, S. and Fukuoka, M. (1998) High P-T Polymetamorphism, Dehydration Melting, and Generation of Migmatites and Granites in the Higher Himalayan Crystalline Complex, Sikkim, India. Journal of Petrology, 39, 61-99. https://doi.org/10.1093/petroj/39.1.61

[3] Rubatto, D., Chakraborty, S. and Dasgupta, S. (2013) Timescales of Crustal Melting in the Higher Himalayan Crystallines (Sikkim, Eastern Himalaya) Inferred from Trace Element-Constrained Monazite and Zircon Chronology. Contributions to Mineralogy Petrology, 165, 349-372. https://doi.org/10.1007/s00410-012-0812-y

[4] Bhattacharyya, K., Mitra, G. and Sanghoon, K. (2015) Geometry and Kinematics of the Darjeeling Sikkim Hiamalaya: Implications for the Evolution of Himalayan Fold Thrust Belt. Journal of Asian Earth Sciences, 113, 778-795. https://doi.org/10.1016/j.jseaes.2015.09.008 
[5] Bhattacharjee, S. and Nandy, S. (2009) Geology of the Western Arunachal Himalaya in Parts of Tawang and West Kameng Districts, Arunachal Pradesh. Journal of the Geological Society of India, 73, 589-590. https://doi.org/10.1007/s12594-009-0043-7

[6] Saha, D. (2013) Lesser Himalayan Sequences in Eastern Himalaya and Their Deformation: Implications for Paleoproterozoic Tectonic Activity along the Northern Margin of India. Precambrian Research, 4, 289-304.

https://doi.org/10.1016/j.gsf.2013.01.004

[7] Chakraborty, S., Anczkiewicz, R., Gaidies, F., Rubatto, D., Sorcar, N, Faak., N., Mukhopadhyay, D. and Dsagupta, S. (2016) A Review of Thermal History and Timescales of Tectonometamorphic Processes in Sikkim Himalaya (NE India) and Implications for Rates of Metamorphic Processes. Journal of Metamorphic Geology, 34, 785-803. https://doi.org/10.1111/jmg.12200

[8] Ahmad, T., Harris, N., Bickle, M., Chapman, H., Bunbury, J. and Prince, C. (2011) Isotopic Constraints on the Structural Relationships between the Lesser Himalayan Series and the Higher Himalayan Crystalline Series, Garhwal Himalaya. GSA Bulletin, 112, 467-477. https://doi.org/10.1130/0016-7606(2000)112<467:ICOTSR >2.0.CO;2

[9] Mottram, C.M., Argles, T.W., Harris, N.B.W., Parrish, R.R., Horstwood, M.S.A., Warren, C.J. and Gupta, S. (2013) Tectonic Interleaving along the Main Central Thrust, Sikkim Himalaya. Journal of Geological Society of London, 171, 255-268. https://doi.org/10.1144/igs2013-064

[10] DiPietro, D.A. and Pogue, K.R. (2004) Tectonostratigraphic Subdivisions of the Himalaya: A View from the West. Tectonics, 23, No. 5. https://doi.org/10.1029/2003TC001554

[11] Beaumont, C., Jamieson, R., Nguyern, M. and Medvedev, S. (2004) Crustal Channel Flows 1: Numerical Models with Tectonic Applications to Himalayan Tibetan Orogen. Journal of Geophysical Research, 109, 1-29. https://doi.org/10.1029/2003/B002809

[12] Searle, M.P. and Szulc, M.G. (2005) Channel Flow and Ductile Extrusion of the high Himalayan Slab the Kangchenjunga-Darjeeling Profile, Sikkim Himalaya. Journal of Asian Earth Sciences, 25, 173-185. https://doi.org/10.1016/j.jseaes.2004.03.004

[13] Chakraborty, S., Mukhopadhyay, D.K., Chowdhury, P., Rubatto, D., Anczkiewicz, R., Trepmann, C., Gaidies, F., Sorcar, N. and Dasgupta, S. (2017) Channel Flow and Localized Fault Bounded Slice Tectonics (LFBST): Insights from Petrological, Structural, Geochronological and Geospeedometric Studies in the Sikkim Himalaya, NE India. Lithos, 282-283, 464-482. https://doi.org/10.1016/j.lithos.2017.01.024

[14] Mukherjee, S. (2013) Channel Flow Extrusion Model to Constrain Dynamic Viscosity and Prandtl Number of the Higher Himalayan Shear Zone. International Journal of earth Science, 102, 1811-1835. https://doi.org/10.1007/s00531-012-0806-Z

[15] van Hinsberg, V., Henry, D.J. and Horst, M. (2011) Tourmaline: An Ideal Indicator of Its Host Environment. The Canadian Mineralogist, 49, 1-16. https://doi.org/10.3749/canmin.49.1.1

[16] Sinha, S. (1982) Himalayan Main Central Thrust and Its Implications for Himalayan Inverted Metamorphism. Tectonophysics, 84, 197-224. https://doi.org/10.1016/0040-1951(82)90160-3

[17] Passchier, C.W. and Trouw, R.S.J. (2005) Microtectonics. Springer-Verlag.

[18] Schenk, O. and Urai, J. (2004) Microstructural Evolution and Grain Boundary Structure during Static Recrystallization in Synthetic Polycrystals of Sodium Chloride Containing Saturated Brine. Contributions to Mineralogy Petrology, 146, 
671-682. https://doi.org/10.1007/s00410-003-0522-6

[19] Ghosh, S., Bose, S., Mandal, N. and Dasgupta, S. (2016) Dynamic Recrystallization Mechanisms and Their Transition in the Daling Thrust (DT) Zone: Darjeeling Sikkim Himalaya. Tectonophysics, 674, 166-181. https://doi.org/10.1016/j.tecto.2016.02.023

[20] Faccenda, M., Gerya, T.V. and Chakraborty, S. (2008) Styles of Post-Subduction Collisional Orogeny: Influence of Convergence Velocity, Crustal Rheology and Radiogenic Heat Production. Lithos, 103, 257-287. https://doi.org/10.1016/j.lithos.2007.09.009

[21] Paul, D.K., Mc. Naughton, N.J., Chattopadhyay, S. and Ray, K.K. (1996) Geochronology and Geochemistry of the Lingtse Gneiss, Darjeeling-Sikkim Himalaya: Revisited. Journal of Geological society of India, 48, 497-506.

[22] Paul, D.K., Chandy, K.C., Bhalla, J.K. and Sengupta, N.R. (1982) Geochronology and Geochemistry of Lingtse Gneiss, Darjeeling-Sikkim Himalaya. Indian Journal of Earth Sciences, 9, 11-17.

[23] Whalen, J.B., Currie, K.L. and Chappell, B. (1987) A Type Granites: Geochemical Characteristics, Discrimination and Petrogenesis. Contributions to Mineralogy Petrology, 95, 407-419. https://doi.org/10.1007/BF00402202

[24] Eby, G.N. (1990) The A-Type Granitoids: A Review of Their Occurrence and Chemical Characteristics and Speculations on Their Petrogenesis. Lithos, 26, 115-134. https://doi.org/10.1016/0024-4937(90)90043-Z

[25] Torres-Ruiz, J., Pesquera, A., Gil-Crespo, P.P. and Velilla, N. (2003) Origin and Petrogenetic Implications of Tourmaline-Rich Rocks in the Sierra Nevada (Betic Cordillera, Southeastern Spain). Chemical Geology, 197, 55-86. https://doi.org/10.1016/S0009-2541(02)00357-1

[26] Burg, J.P. and Vigneresse, J.L. (2002) Non-Linear Feedback Loop in the Rheology of Cooling 360 Crystallizing Felsic Magma and Heating-Melting Felsic Rock. Geological Society of London, Special Publications, 200, 275-292. https://doi.org/10.1144/GSL.SP.2001.200.01.16

[27] Bhattacharyya, K. and Mitra, G. (2011) Strain Softening along the MCT Zone from the Sikkim Himalaya: Relative Roles of Quartz and Micas. Journal of Structural Geology, 33, 1105-1121. https://doi.org/10.1016/j.jsg.2011.03.008

[28] Bhattacharyya, K. and Mitra, G. (2014) Spatial Variations in Deformation Mechanisms along the Main Central Thrust Zone: Implications for the Evolution of the MCT in the Darjeeling-Sikkim Himalaya. Journal of Asian earth Sciences, 96, 132-147. https://doi.org/10.1016/j.jseaes.2014.08.035

[29] Kretz, R. (1983) Symbols for Rock Forming Minerals. American Mineralogist, 68, 277-279. 